\title{
Heavy metal analysis of Otamiri River in Imo state, South-Eastern Nigeria
}

\begin{abstract}
This study assesses the heavy metal concentration of Otamiri River in Imo State, Nigeria. Standard sampling and analytical methods were employed during the study. The result shows that in all eleven (11) surface water samples collected, mercury $(\mathrm{Hg})$ and cadmium $(\mathrm{Cd})$ have the least concentrations which are below $0.0001 \mathrm{mg} / 1$ and below the World Health Organization limits of $0.001 \mathrm{mg} / 1$ for mercury and $0.003 \mathrm{mg} / 1$ for cadmium. Copper $(\mathrm{Cu})$ showed a very low concentration of less than $0.0001 \mathrm{mg} / 1$ in sample 1 collected at the river source in Egbu and also anomalously very low concentration of less than $0.0001 \mathrm{mg} / 1$ in sample 5 collected at Umuoma Nekede. The highest concentration of copper $(\mathrm{Cu})(0.0271 \mathrm{mg} / \mathrm{l})$ is noticed in sample 8 collected within FUTO community which is likely to have been introduced by domestic waste water from the University hostels that drain into the Otamiri river. The concentration of copper $(\mathrm{Cu})$ in the other eight samples falls within the range of $0.0032 \mathrm{mg} / 1-0.0271 \mathrm{mg} / 1$ and the average concentration of copper $(\mathrm{Cu})$ in all the eleven (11) surface water samples is $0.0039 \mathrm{mg} / 1$ and all these levels of copper $(\mathrm{Cu})$ concentrations in Otamiri river were below the World Health Organization (WHO) limit of $2 \mathrm{mg} / 1$ for copper $(\mathrm{Cu})$ in surface water. Also the concentration of zinc $(\mathrm{Zn})$ ranges from $0.0033 \mathrm{mg} / \mathrm{l}$ in sample 1 to $0.1377 \mathrm{mg} / 1$ in sample 7. Samples 7, 10 and 11 collected at Umuchima secondary school, Imo State polytechnic Umuagwo and Ohaji Egbema community showed the highest concentration of $0.1377 \mathrm{mg} / 1,0.1143 \mathrm{mg} / 1$ and $0.1039 \mathrm{mg} / 1$ respectively and the average zinc $(\mathrm{Zn})$ concentration in all eleven (11) samples is $0.0513 \mathrm{mg} / \mathrm{l}$. The concentration of iron $(\mathrm{Fe})$ in all eleven (11) surface water samples are above $0.20 \mathrm{mg} / 1$ which shows that the river has a high concentration of iron $(\mathrm{Fe})$ and the average concentration of iron $(\mathrm{Fe})$ in the sample is $0.2426 \mathrm{mg} / \mathrm{l}$, with concentration ranging from $0.21 \mathrm{mg} / 1$ in sample 1 to $0.28 \mathrm{mg} / 1$ in sample 2 collected from the river source in Egbu and behind Owerri slaughter respectively. It is recommended that regular monitoring of the Otamiri River be carried out to monitor pollution levels.
\end{abstract}

Keywords: heavy metal, surface water, otamiri river
Volume I Issue 5 - 2017

\author{
Onyekuru SO,' Nwankwoala HO, ${ }^{2}$ Uzor I' \\ 'Department of Geosciences, Federal University of Technology, \\ Nigeria \\ ${ }^{2}$ Department of Geology, University of Port Harcourt, Nigeria
}

Correspondence: Nwankwoala HO, Department of Geology, University of Port Harcourt, Nigeria,

Email nwankwoala_ho@yahoo.com

Received: August 23, 2017| Published: November 30, 2017

\section{Introduction}

Surface water is used for a variety of purposes like drinking, washing, bathing, recreation as well as numerous other varied industrial applications. The wholesomeness of these surface waters has become an issue of great concern. Water pollution is a burning issue all over the world. In recent years an increasing awareness has developed on the impact of human activities on the environment because our environment has witnessed a continuous and rapid deterioration which cause pollution in all its abiotic and biotic components. According to a World Health Organization report on guideline for drinking water, ${ }^{1}$ safe drinking-water, as defined by the Guidelines, does not represent any significant risk to health over a lifetime of consumption; including different sensitivities that may occur between life stages. For this reason, particular concern has become apparent regarding the adequacy of the quality of water resource; both surface and groundwater resources. The impact of human activities in the urban, municipal and populated area makes surface water bodies like streams, river, lagoons, etc, and ground water bodies to be susceptible to contamination from pollutants. Pollution of soil and water by heavy metal occurs due to industrial wastes, application of fertilizer, corrosion of sheeting, wires, pipes, and burning of coal and wood. ${ }^{2}$

These pollutants include; heavy metals, industrial chemicals, sewage, etc discharged from sources like urban runoffs, industrial waste waters, sewage treatment plants, chemical fishing activities, leachate from refuse dumps, agricultural fertilizer application, etc. of all the above mentioned pollutants released into water bodies, heavy metals are the most persistent in the environment and also very toxic. The term heavy metal refers to metallic chemical elements that have relatively high density and are toxic or poisonous at low concentration values. They are natural components of the Earth's crust that cannot be degraded or destroyed, which would mainly include the transition metals, some metalloids, lanthanides and actinides. Examples include copper, zinc, selenium, iron, lead, mercury, cadmium and silver etc. Heavy metals are also classified based on density, atomic weight, chemical toxicity in relation to living organisms. Heavy metals can cause serious health effect with different symptoms depending on the nature and quality of the metal ingested. ${ }^{3}$ The pollution estimates of the Rivers Nworie, Otamiri, Imo, Aba and Mbaa were studied. ${ }^{4-6}$ The objectives of this study is to analyze the level of heavy metal concentration in Otamiri River in Imo State, South Eastern Nigeria as well as to delineate the possible sources of heavy metal in the river if found in concentration above the World Health Organization (WHO) drinking water standard.

\section{The study area description}

The study area (Figure 1) has a relatively uniform topography and is low lying; being generally about 300 meters above sea level. The main stream draining the area is the Otamiri River, the river runs from Egbu where it has its source through; the Owerri timber market where 
it confluences with Nworie River before moving down to Nekede, Ihiagwa, Eziobodo, Emeabiam, Mgbirichi, Umuagwo and finally to Ozuzu in Etche town of Rivers State where it joins the Imo River to the Atlantic Ocean in the South.

The Otamiri River is of great economic significance to the people of the communities where it passes and it serves as a source of domestic water for those that do not have boreholes. ${ }^{7}$ For example, tanker drivers go and collect water from the river around the Egbu axis of the river. Sand and gravel mining is going on along the river channel from the Nekede axis down to as far as Umuagwo. Fishing activities has been noticed around the river confluence with Nworie River.

\section{Fieldwork and sample collection}

The field study was carried out along the Otamiri River channel

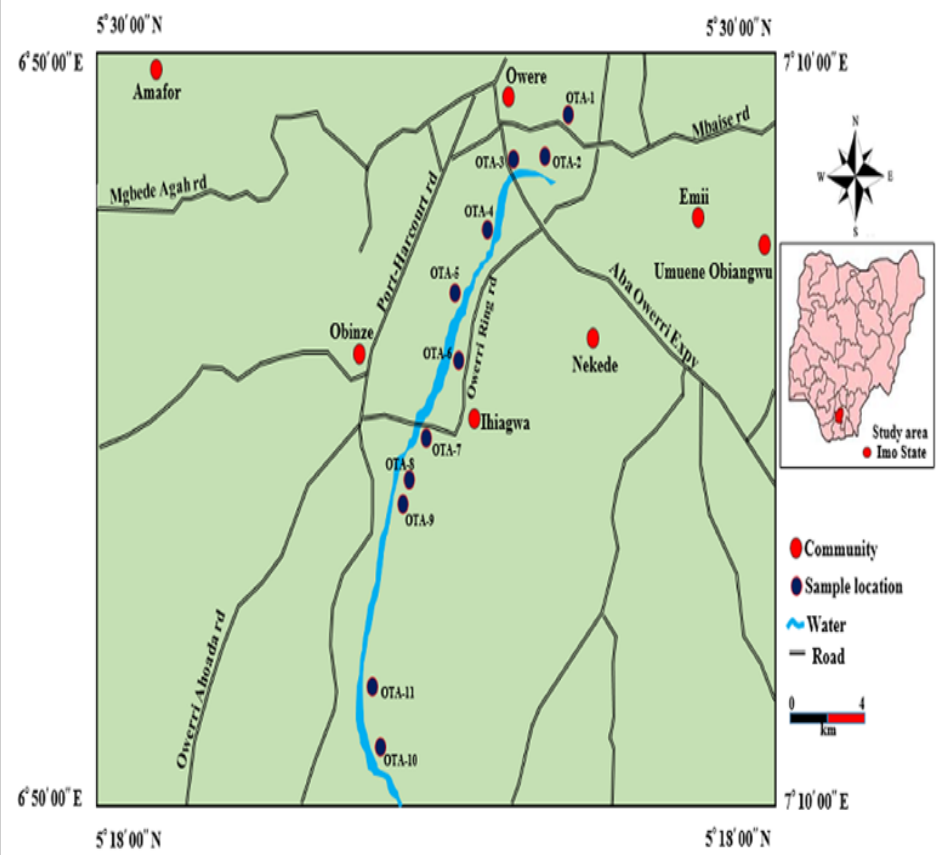

Figure I Map of the Study Area Showing Sampling Locations.

Table I Sample locations and their coordinates

\begin{tabular}{lll}
\hline Sample & Location & Coordinate \\
\hline OTA - I & Water source at Egbu & $05^{\circ} 28^{\prime} 59^{\prime \prime} \mathrm{N}, 07^{\circ} 04^{\prime} 0 \mathrm{I}^{\prime \prime} \mathrm{E}$ \\
OTA - 2 & Along Egbu road behind the Slaughter & $05^{\circ} 28^{\prime} \mathrm{I} 9^{\prime \prime} \mathrm{N}, 07^{\circ} 03^{\prime} \mathrm{I} 4^{\prime \prime} \mathrm{E}$ \\
OTA - 3 & Behind the Owerri timber market & $05^{\circ} 28^{\prime} 16^{\prime \prime} \mathrm{N}, 07^{\circ} 02^{\prime} 2 \mathrm{I}^{\prime \prime} \mathrm{E}$ \\
OTA - 4 & Sand dredging site at old Nekede road & $05^{\circ} 27^{\prime} 00^{\prime \prime} \mathrm{N}, 07^{\circ} 0 \mathrm{I}^{\prime} 35^{\prime \prime} \mathrm{E}$ \\
OTA - 5 & Under a collapsed bridge within Nekede community & $05^{\circ} 26^{\prime} 03^{\prime \prime} \mathrm{N}, 07^{\circ} 00^{\prime} 45^{\prime \prime} \mathrm{E}$ \\
OTA - 6 & Behind police college Nekede & $05^{\circ} 24^{\prime} 56^{\prime \prime} \mathrm{N}, 07^{\circ} 00^{\prime} 42^{\prime \prime} \mathrm{E}$ \\
OTA - 7 & Behind Umuchima Secondary School & $05^{\circ} 23^{\prime} 499^{\prime \prime} \mathrm{N}, 06^{\circ} 59^{\prime} 46^{\prime \prime} \mathrm{E}$ \\
OTA - 8 & Just after Otamiri bridge inside FUTO & $05^{\circ} 23^{\prime} 06^{\prime \prime} \mathrm{N}, 06^{\circ} 59^{\prime} 4^{\prime \prime} \mathrm{E}$ \\
OTA - 9 & Sand dredging site in Eziobodo & $05^{\circ} 22^{\prime} 47^{\prime \prime} \mathrm{N}, 06^{\circ} 59^{\prime} 04^{\prime \prime} \mathrm{E}$ \\
OTA - I0 & Sand dredging site close Imo State Polytechnic Umuagwo & $05^{\circ} 18^{\prime} 48^{\prime \prime} \mathrm{N}, 06^{\circ} 58^{\prime} \mathrm{I} 7^{\prime \prime} \mathrm{E}$ \\
OTA - II & Ohaji-Egbema community & $05^{\circ} 195^{\prime \prime} \mathrm{N}, 06^{\circ} 58^{\prime} 03^{\prime \prime} \mathrm{E}$ \\
\hline
\end{tabular}

starting from the river source in Egbu Owerri down to Ohaji Egbema Local Government Local Area all in Imo state. Surface water samples were collected at every two (2) kilometre intervals, at points were the river could be accessed from and visual studies made. Observations were made with respect to the rivers; flow rate, colour and nature of the surroundings. Due to thick vegetation along the river channel, the river could not be accessed at some points and so access to the river was done through the points of less vegetative cover. During sample collection, the plastic sample bottle was rinsed with the river water before being used for collection. In all, eleven (11) surface water samples were collected and the coordinate of the sample spot was measured using a phone installed GPS as listed in Table 1 below, the plastic bottles were tightly covered, sealed with masking tapes, labelled and taken to the laboratory for heavy metal analysis. 


\section{Results and discussion}

The result of the analysis carried out for the concentration in milligram per litre $(\mathrm{mg} / \mathrm{l})$ of five $(5)$ heavy metals: copper $(\mathrm{Cu})$, Cadmium $(\mathrm{Cd})$, mercury $(\mathrm{Hg})$, zinc $(\mathrm{Zn})$ and iron $(\mathrm{Fe})$ in eleven (11) surface water samples from Otamiri River is shown in Table 1. Generally, from the analysis carried out; iron (Fe) has the highest concentration followed by zinc $(\mathrm{Zn})$ before copper $(\mathrm{Cu})$ and finally mercury $(\mathrm{Hg})$ and cadmium $(\mathrm{Cd})$ with concentrations tending towards zero in all samples ( $\mathrm{Fe}>\mathrm{Zn}>\mathrm{Cu}>\mathrm{Hg}$ and $\mathrm{Cd}$ ), with exceptions in samples two (2) and three (3) where copper $(\mathrm{Cu})$ have higher concentration than zinc ( $\mathrm{Zn})$.

The result shows that in all eleven (11) surface water samples collected (Table 2), mercury ( $\mathrm{Hg})$ and cadmium $(\mathrm{Cd})$ have the least concentrations which are below $0.0001 \mathrm{mg} / 1$ and is well below the World Health Organization limits of $0.001 \mathrm{mg} / 1$ for mercury and $0.003 \mathrm{mg} / \mathrm{l}$ for cadmium. The Otamiri River therefore does not have any threat of mercury and cadmium contamination and pollution. This is possible due to the lack of industries that uses mercury and cadmium as raw materials for productions or as by-products.

Table 2 Laboratory Results of the Concentration of Heavy Metals in mg/l from Otamiri River.

\begin{tabular}{llllll}
\hline Samples & $\begin{array}{l}\mathrm{Cu} \\
(\mathrm{mg} / \mathrm{l})\end{array}$ & $\begin{array}{l}\mathrm{Cd} \\
(\mathrm{mg} / \mathrm{l})\end{array}$ & $\begin{array}{l}\mathrm{Hg} \\
(\mathrm{mg} / \mathrm{l})\end{array}$ & $\begin{array}{l}\mathrm{Zn} \\
(\mathrm{mg} / \mathrm{l})\end{array}$ & $\begin{array}{l}\mathrm{Fe} \\
(\mathrm{mg} / \mathrm{l})\end{array}$ \\
\hline 1 & $<0.0001$ & $<0.0001$ & $<0.0001$ & 0.0033 & 0.21 \\
2 & 0.0062 & $<0.0001$ & $<0.0001$ & 0.0047 & 0.28 \\
3 & 0.0163 & $<0.0001$ & $<0.0001$ & 0.0118 & 0.22 \\
4 & 0.0108 & $<0.0001$ & $<0.0001$ & 0.0458 & 0.228 \\
5 & $<0.0001$ & $<0.0001$ & $<0.0001$ & 0.0156 & 0.27 \\
6 & 0.0039 & $<0.0001$ & $<0.0001$ & 0.062 & 0.215 \\
7 & 0.0109 & $<0.0001$ & $<0.0001$ & 0.1377 & 0.255 \\
8 & 0.0271 & $<0.0001$ & $<0.0001$ & 0.0441 & 0.251 \\
9 & 0.0032 & $<0.0001$ & $<0.0001$ & 0.0206 & 0.27 \\
10 & 0.0117 & $<0.0001$ & $<0.0001$ & 0.1143 & 0.22 \\
11 & 0.0125 & $<0.0001$ & $<0.0001$ & 0.1039 & 0.25 \\
\hline
\end{tabular}

Copper $(\mathrm{Cu})$ showed a very low concentration of less than $0.0001 \mathrm{mg} / 1$ in sample1 collected at the river source in Egbu and also anomalously very low concentration of less than $0.0001 \mathrm{mg} / \mathrm{l}$ in sample 5 collected at Umuoma Nekede, the result in sample 5 is anomalous in the sense that the sample spot is within a populated region and have refuse dumps close-by and yet results showed a very low concentration of copper $(\mathrm{Cu})$. The highest concentration of copper $(\mathrm{Cu})(0.0271 \mathrm{mg} / \mathrm{l})$ is noticed in sample 8 collected within FUTO community which is likely to have been introduced by domestic waste water from the University hostels that drain into the Otamiri river. The concentration of copper $(\mathrm{Cu})$ in the other eight samples $(2,3,4,6,7,9,10$ and 11) falls within the range of $0.0032 \mathrm{mg} / 1-0.0271 \mathrm{mg} / \mathrm{l}$ and the average concentration of copper $(\mathrm{Cu})$ in all the eleven (11) surface water samples is $0.0039 \mathrm{mg} / \mathrm{l}$ and all these levels of copper $(\mathrm{Cu})$ concentrations in Otamiri river are well below the World Health Organization (WHO) limit of $2 \mathrm{mg} / \mathrm{l}$ for copper $(\mathrm{Cu})$ in surface water.

Also the concentration of zinc $(\mathrm{Zn})$ ranges from $0.0033 \mathrm{mg} / \mathrm{l}$ in sample 1 to $0.1377 \mathrm{mg} / 1$ in sample 7. Samples 7, 10 and 11 collected at; Umuchima secondary school, Imo State polytechnic Umuagwo and Ohaji Egbema community shows the highest concentration of $0.1377 \mathrm{mg} / 1,0.1143 \mathrm{mg} / 1$ and $0.1039 \mathrm{mg} / 1$ respectively and the average zinc $(\mathrm{Zn})$ concentration in all eleven (11) samples is $0.0513 \mathrm{mg} / \mathrm{l}$. According to the World Health Organization (WHO, 2008) guideline for drinking water, zinc $(\mathrm{Zn})$ concentrations are up to $0.01 \mathrm{mg} / \mathrm{l}$ for surface water and $0.05 \mathrm{mg} / 1$ for groundwater and concentration above $3 \mathrm{mg} / 1$ may not be accepted. In all eleven (11) surface water samples analysed, none of them have concentrations of zinc $(\mathrm{Zn})$ up to the World Health Organisations limits of $3 \mathrm{mg} / 1$ for Zinc $(\mathrm{Zn})$ in surface water, but the little amount of zinc ( $\mathrm{Zn}$ ) found in the water could have been introduced from various sources like; rusted zinc corrugated roofing sheets, runoff water from metal scrapes collection sites, and also possibly from runoff water from the Nekede mechanic village.

Iron $(\mathrm{Fe})$ showed the highest concentration of all five (5) heavy metals analyzed for in the samples. It is noticed that the concentration of iron (Fe) in all eleven (11) surface water samples are above $0.20 \mathrm{mg} / 1$ which shows that the river have a high concentration of iron $(\mathrm{Fe})$ and the average concentration of iron $(\mathrm{Fe})$ in the samples is $0.2426 \mathrm{mg} / 1$, ranging from $0.21 \mathrm{mg} / 1$ in sample 1 to $0.28 \mathrm{mg} / \mathrm{l}$ in sample 2 collected from the river source in Egbu and behind Owerri slaughter respectively. With reference to the World Health Organization standard of $0.2 \mathrm{mg} / 1$, the Otamiri River have an iron concentration that is above normal and as such, the river is polluted with iron. The sources of the river's iron $(\mathrm{Fe})$ pollution are majorly point sources like refuse dumps, runoff from metal scrape collection sites, runoff from Nekede mechanic village, an iron smelting company at garage and runoff from roadside welding workshops. Table 3 shows the average heavy metal concentrations while Table 4 shows the comparison of the heavy metal concentration in Otamiri River with the WHO guideline for Drinking Water Quality. ${ }^{1}$ According to the World Health Organization guideline for drinking water quality, ${ }^{1}$ iron $(\mathrm{Fe})$ concentration of less than $0.3 \mathrm{mg} / 1$ will not have a noticeable taste in water and as such the river water can still be used by people for domestic purposes without them noticing the impending health hazard of using the river for domestic purposes.

Table 3 Average Heavy Metal Concentrations

\begin{tabular}{llll}
\hline $\begin{array}{l}\text { Heavy } \\
\text { metal }\end{array}$ & $\begin{array}{l}\text { Total } \\
\text { concentration } \\
(\mathrm{mg} / \mathrm{I})\end{array}$ & $\begin{array}{l}\text { Total conc.l } \\
\text { Number of samples }\end{array}$ & Average \\
\hline $\mathrm{Cu}$ & 0.1028 & $0.1028 \div 11$ & 0.0093 \\
$\mathrm{Cd}$ & 0.0011 & $0.0011 \div 11$ & 0.0001 \\
$\mathrm{Hg}$ & 0.0011 & $0.0011 \div 11$ & 0.0001 \\
$\mathrm{Zn}$ & 0.5638 & $0.5638 \div 11$ & 0.0513 \\
$\mathrm{Fe}$ & 2.669 & $2.669 \div 11$ & 0.2426 \\
\hline
\end{tabular}


Table 4 Comparison of the Heavy Metal Concentration in Otamiri River with the WHO guideline for Drinking Water Quality (2008)

\begin{tabular}{|c|c|c|c|c|c|c|c|c|c|c|c|c|}
\hline \multirow[t]{2}{*}{$\begin{array}{l}\text { Heavy } \\
\text { metal }\end{array}$} & \multirow[t]{2}{*}{$\begin{array}{l}\text { WHO } \\
\text { limits } \\
(\mathrm{mg} / \mathrm{l})\end{array}$} & \multicolumn{11}{|c|}{$\begin{array}{l}\text { Concentration in samples } \\
(\mathrm{mg} / \mathrm{l})\end{array}$} \\
\hline & & I & 2 & 3 & 4 & 5 & 6 & 7 & 8 & 9 & 10 & 11 \\
\hline $\mathrm{Cu}$ & 2 & $<0.0001$ & 0.0062 & 0.0163 & 0.0108 & $<0.0001$ & 0.0039 & 0.0109 & 0.0271 & 0.0032 & 0.0117 & 0.0125 \\
\hline $\mathrm{Cd}$ & 0.003 & $<0.0001$ & $<0.0001$ & $<0.0001$ & $<0.0001$ & $<0.0001$ & $<0.0001$ & $<0.000 \mathrm{I}$ & $<0.0001$ & $<0.0001$ & $<0.000 \mathrm{I}$ & $<0.0001$ \\
\hline $\mathrm{Hg}$ & 0.001 & $<0.0001$ & $<0.0001$ & $<0.0001$ & $<0.0001$ & $<0.0001$ & $<0.0001$ & $<0.0001$ & $<0.0001$ & $<0.0001$ & $<0.0001$ & $<0.0001$ \\
\hline $\mathrm{Zn}$ & 3 & 0.0033 & 0.0047 & 0.0118 & 0.0458 & 0.0156 & 0.062 & 0.1377 & $0.044 I$ & 0.0206 & 0.1143 & 0.1039 \\
\hline $\mathrm{Fe}$ & 0.2 & 0.21 & 0.28 & 0.22 & 0.228 & 0.27 & 0.215 & 0.255 & 0.251 & 0.27 & 0.22 & 0.25 \\
\hline
\end{tabular}

\section{Conclusion}

Heavy metal analysis carried out in eleven (11) surface water samples for five (5) different metals to ascertain the Otamiri River's suitability for domestic use when compared to the World Health Organization (WHO) standard for drinking water revealed that mercury $(\mathrm{Hg})$ and cadmium $(\mathrm{Cd})$ are present in the river in very minute amount of less than $0.0001 \mathrm{mg} / \mathrm{l}$. Copper $(\mathrm{Cu})$ was also found to be present in the river in small amount on the average of $0.0093 \mathrm{mg} / 1$ which does not pose a threat for domestic use. Also zinc $(\mathrm{Zn})$ was found present in the water in small amount on the average of 0.0513 $\mathrm{mg} / \mathrm{l}$, but iron $(\mathrm{Fe})$ was found to have average concentration of 0.2426 $\mathrm{mg} / 1$ which was above the $\mathrm{WHO}^{8}$ standard for drinking water of 0.2 $\mathrm{mg} / \mathrm{l}$. Because of the high rate of ignorance and lack of awareness of these heavy metals by the general public and professionals, there is need for regular monitoring of Otamiri River and other surrounding rivers for heavy metal contamination and pollution. An awareness programme should be carried out from time to time so as to enlighten the general public of the iron (Fe) contamination of the Otamiri River. A sanitary waste dumps should be used to replace open waste dumps scattered all over Owerri town, so as to prevent leachate migration to the nearby rivers. ${ }^{9}$

\section{Acknowledgements}

The authors thank the Department of Geology, Federal University Owerri for the opportunity to carry out this work.

\section{Conflict of interest}

The authors declare that there is no conflict of interest.

\section{References}

1. WHO. Guidelines for Drinking-Water Quality. Second addendum, 3rd edn. Wolrd Health Organization, Geneva, Switzerland; 2008.

2. Nwankwoala PO, Ekpewerechi PO. Human Activities and Heavy Metal Concentrations in Aba River, Abia State, Nigeria. British Journal of Earth Sciences Research. 2017;5(1):26-36.

3. Njiiar GN, Iwara AI, Offong RA, et al. Assessment of Heavy Metal Status of Boreholes in Calabar South Local Government Area, Cross River State Nigeria. Ethiopian Journal of Environmental Science and Management. 2012;5(1):25-32.

4. Obodo GA. Pollution estimates of river Nworie, Otamiri, Imo, Aba and Mbaa. The Physical Scientist. 2002;1:27-33.

5. Amadi AN. Quality Assessment of Aba River Using Heavy metal Pollution Index. American Journal of Environmental Engineering. 2012;2(1):45-49.

6. Amadi AN, Nwankwoala HO. Evaluation of Heavy Metal in Soils from Enyimba Dumpsites in Aba, Southeastern Nigeria Using Contamination Factor and Geo- Accumulation Index. Energy and Environment Research. 2013;3(1):125-134.

7. Uma KO. Water resources of Owerri and its environs, Imo State, Nigeria. Journal of Mining and Geology. 1989;22(91-92):57-64.

8. WHO. Guidelines for Drinking-water Quality, 4th edn. incorporating the first and second addenda, World Health Organisation, Geneva, Switzerland; 2011.

9. Nwachukwu SU, Akpata TVI, Essien ME. Microbiological Assessment of industrial Sewage of Agbara Industrial Estate in Ogun state. International Journal of Ecology and Environmental Sciences. 1989;15:109-115. 